\title{
PERBEDAAN UMUR BIBIT TERHADAP PERTUMBUHAN DAN PRODUKSI PADI SAWAH (Oryza sativa L)
}

\section{EFFECTS OF AGE DIFFERENCES OF SEEDS ON GROWTH AND PRODUCTION OF PADDY RICE (Oryza sativa L)}

\section{Vikson J. Porong*)}

")Jurusan Budidaya Pertanian Fakultas Pertanian Unsrat Manado

\begin{abstract}
This study used a randomized block design with five standard treatments as follows: A1 (15 days), A2 (20 days), A3 ( 25 days), A4 (30 days), A5 (35 days). The treatment was repeated three times. The purpose of this study was to obtain the best age of the seeds in order to obtain high growth and production. The results of statistical analysis showed that there was no siginifcant difference in the number of unproductive tillers 70 days after transplanting, but this was not the case for the leaf area index; 70 days after germination there was a significant difference. A1 treatment (15 days) had the highest LAl is 4,56. The same result was shown in the weight of 1000 grains of rice where there was a significant difference among treatments; $A 1$ treatment (15 days) weighted 31.12. It was concluded that the age of seedlings after transplanting had a significant effect on LAI and 1000 grain weight of rice grain after harvest.
\end{abstract}

Keywords: Rice, seedling, transplanting

\begin{abstract}
Penelitian ini menggunakan rancangan acak kelompok dengan lima taraf perlakuan sebagai berikut : A1 (15 hari), A2 (20 hari), A3 (25 hari), A4 (30 hari), A5 (35 hari). Perlakuan diulang sebanyak tiga kali. Tujuan penelitian ini untuk mendapatkan umur bibit yang tepat sehingga diperoleh pertumbuhan yang tinggi. Hasil analisis statistika menunjukkan bahwa tidak terdapat perbedaan yang nyata pada jumlah anakan yang tidak produktif 70 hari setelah pindah tanam namun pada indeks luas daun 70 hari setelah berkecambah terdapat suatu perbedaan yang nyata, terlihat pada perlakuan A1 (15 hari) memiliki ILD tertinggi yaitu 4,56. Hal yang sama terlihat pada bobot gabah 1000 butir terdapat suatu perbedaan yang nyata antara perlakuan yaitu pada perlakuan A1 (15 hari) memiliki bobot tinggi yaitu 31,12. Disimpulkan bahwa umur bibit setelah pindah tanam sangat berpengaruh pada ILD dan bobot gabah 1000 butir padi setelah panen.
\end{abstract}

Kata kunci: Padi, bibit, pindah tanam

Eugenia Volume 18 No. 1 April 2012 


\section{PENDAHULUAN}

Negara kita diperhadapkan pada masalah pertumbuhan jumlah penduduk yang tidak diimbangi dengan peningkatan luas lahan untuk padi sawah. Selain itu menurunnya produksi padi disebabkan karena masyarakat kurang menerapkan teknologi yang dianjurkan oleh pemerintah (Nataatmadja, dkk., 1988). Lahan sawah sudah berubah fungsi menjadi areal pemukiman, perkantoran, areal industri dan prasarana jalan.

Padi sawah umumnya ditanam dengan cara pindah tanam melalui persemaian atau dengan cara ditaburkan secara langsung (Pitojo, 1997). Bibit padi sawah siap untuk pindah tanam apabila sudah memiliki organ tanaman yang lengkap. Umur bibit merupakan komponen yang paling penting dalam pertumbuhan dan produksi yang tinggi dan dapat mempengaruhi jumlah anakan padi (Vergara, 1985). Kenyataan bagi kebanyakan petani bahwa sistem persemaian yang diterapkan kurang memperhatikan kapan umur bibit yang tepat untuk siap pindah tanam.

Menurut De data (1981) umur bibit optimum untuk dipindah tanam sangatlah penting dalam hubungannya dengan perkembangan tanaman dan hasil. Ada beberapa pendapat dalam hal umur bibit padi dalam hubungannya dengan hasil dan pertumbuhan tanaman yaitu: a) bibit dapat dipindah tanam setelah berumur 30 hari (Anonymous, 1972); b) bibit dapat dicabut dan dipindah tanam setelah bibit sudah berdaun 5 helai pada umur sekitar 20-23 hari (Soemartono, dkk., 1980).

\section{METODE PENELITIAN}

Penelitian ini dilaksanakan di Desa Laikit Kecamatan Airmadidi selama tiga bulan sejak Bulan September - Nopember 2005.
Perlakuan yang diuji terdiri atas 5 taraf umur bibit yaitu:

$\mathrm{A} 1=$ umur bibit 15 hari setelah sebar

$\mathrm{A} 2=$ umur bibit 20 hari setelah sebar

$\mathrm{A} 3=$ umur bibit 25 hari setelah sebar

A4 $=$ umur bibit 30 hari setelah sebar

A5 = umur bibit 35 hari setelah sebar

Penelitian ini dilaksanakan dengan menggunakan Rancangan Acak Kelompok (RAK) dan setiap perlakuan diulang 3 kali.

Data dianalisis keragamannya dengan sidik ragam dan dilanjutkan dengan Uji Beda Nyata terkecil (BNT).

Benih yang digunakan adalah benih varietas membramo dan lahan persemaian digunakan 5 petak dimana ukuran petak satu meter persegi $(1 \mathrm{~m} \times 1 \mathrm{~m})$. Benih yang ditabur direndam dalam air selama 24 jam kemudian benih ditabur secara merata pada petak yang telah disiapkan.

Setelah bibit dipersemaian berumur 15 , 20, 25, 30 dan 35 hari, dicabut dan dipindahkan ke lahan yang ada. Penanaman dengan sistem latihan dengan jarak tanam $20 \times 30 \mathrm{~cm}$.

Variabel pengamatan yaitu: 1) jumlah anakan yang tidak produktif pada 70 hari setelah dipindah tanam, 2) indeks luas daun pada 70 hari setelah pindah tanam. Persamaannya adalah: ILD= Luas Daun per tunas $x$ jumlah daun pertunas $x$ jumlah tunas per rumpun $x$ jumlah rumpun per petak. Luas daun $=P$ daun $\times L$ daun $\times k$ pindah tanam. $K=0,75$ (untuk strata atas, strata tengah dan strata bawah). 3) bobot gabah 1000 butir kering panen (gram) (Yoshida,1981).

\section{HASIL DAN PEMBAHASAN}

\section{Jumlah Anakan yang Tidak Produktif 20 Hari Setelah Pindah Tanam}

Hasil penelitian menujukan bahwa jumlah anakan tidak produktif pada 70 hari setelah pindah tanam sebagai berikut: 
Tabel 1. Rata-rata Jumlah Anakan yang Tidak Produktif 70 Hari Setelah Pindah Tanam

(Table 1. The Average Number of Unproductive Tillers 70 Days After Planting Move

\begin{tabular}{cc}
\hline Perlakuan (umur bibit setelah sebar) & Pengamatan $(70 \mathrm{hr}$ setelah pindah tanam) \\
\hline 15 hari & 2,59 \\
20 hari & 4,32 \\
25 hari & 2,21 \\
30 hari & 3,83 \\
35 hari & 2,78 \\
BNT 5\% & tn \\
\hline
\end{tabular}

Keterangan: Angka yang diikuti oleh huruf yang sama pada kolom yang sama berbeda tidak nyata

Tabel 2. Rata-rata Indeks Luas Daun pada 70 Hari Setelah Berkecambah

(Table 2. Average Leaf Area Index at 70 Days After Germination)

\begin{tabular}{cc}
\hline Perlakuan (umur bibit setelah sebar) & Pengamatan $(70 \mathrm{hr}$ setelah berkecambah \\
\hline 15 hari & $4,56 \mathrm{c}$ \\
20 hari & $2,79 \mathrm{~b}$ \\
25 hari & $2,04 \mathrm{a}$ \\
30 hari & $1,85 \mathrm{a}$ \\
35 hari & $1,18 \mathrm{a}$ \\
BNT $5 \%$ & 0,904 \\
\hline
\end{tabular}

Keterangan: Angka yang diikuti oleh huruf yang sama pada kolom yang sama berbeda tidak nyata

Tabel 3. Rata-rata Bobot Gabah 1000 Butir (gram)

(Table 3. Average Grain 1000 Grain Weight (grams))

\begin{tabular}{cc}
\hline Perlakuan (umur bibit setelah sebar) & Pengamatan (panen) \\
\hline 15 hari & $31,12 \mathrm{~b}$ \\
20 hari & $29,52 \mathrm{a}$ \\
25 hari & $30,13 \mathrm{a}$ \\
30 hari & $29,87 \mathrm{a}$ \\
35 hari & $29,68 \mathrm{a}$ \\
BNT 5\% & 0,703
\end{tabular}

Keterangan: Angka yang diikuti oleh huruf yang sama pada kolom yang sama berbeda tidak nyata

Dari tabel 1 terlihat bahwa jumlah angka tidak produktif yang tertinggi adalah 4,32 pada taraf perlakuan 20 hari, meskipun antara taraf perlakuan tidak berbeda nyata.

\section{Indeks Luas Daun pada 70 Hari Setelah Bekecambah}

Hasil penelitian menunjukan bahwa indeks luas daun pada 70 hari setelah berkecambah dapat dilihat pada Tabel 2. Berdasarkan tabel 2 terlihat bahwa umur bibit memberi pengaruh yang nyata terhadap ILD dan nilai ILD tertinggi pada taraf perlakuan 15 hari (rata-rata 4,56 yang berbeda nyata dengan taraf perlakuan lainnya. Sedangkan antara taraf perlakuan 25 hari, 30 hari, dan 35 hari tidak berbeda nyata.

\section{Bobot Gabah 1000 Butir}

Hasil penelitian menunjukan bahwa bibit gabah 1000 butir dapat dilihat pada Tabel 3. Dari tabel 3 terlihat bahwa umur bibit berpengaruh nyata dan tertinggi pada taraf perlakuan 25 hari dan berbeda nyata dengan taraf perlakuan lainnya.

Faktor internal dari tanaman serta faktor lingkungan lebih berpengaruh terhadap pertumbuhan dan produksi padi. Efisiensi penggunaan cahaya serta kompetisi antar tanaman dalam menggunakan air dan unsur hara memberi 
hasil yang berbeda dan pengaruh yang nyata (Harjadi Setyati, 1983). Pengaruh umur bibit terlihat pada ILD dan bobot gabah 1000 butir.

\section{KESIMPULAN}

Umur bibit 15 hari adalah yang tepat untuk pindah tanam. Terdapat pengaruh yang nyata pada ILD dan bobot gabah 1000 butir padi setelah panen.

\section{DAFTAR PUSTAKA}

Anonymous, 1972. Padi Sawah. Penerbit Nusa Indah Lembaga Penelitian dan Pembangunan Sosial NTT, LPPS/NTT, Maumere/ Nita, Flores.

De data. S.K. 1981. Principle and Practices of Rice Production. A Willey Interscienmce publication John Willey Q Sons. New York.
Harjadi Setyati. S.M.M. 1983. Pengantar Agronomi. PT. Gramedia Jakarta

Yoshida, S. 1981. Fundamentals of Rice Crop Science. International Rice Research Inctitute. Los Banos Philipines.

Nataatmadja, H., Kertosastro, D. dan Suryana, A. 1988. Perkembangan Produksi dan Kebijaksanaan Pemerintah dalam Produksi Beras Dalam Padi (buku 1). Badan Penelitian dan Pengembagan Pertanian. Bogor.

Pitojo, S. 1977. Budidaya Padi Sawah Tabela. PT. Penebar swadaya. Jakarta.

Soemartono, Bahrin Somad dan Hardjono R. 1980. Bercocok Tanam Padi. Penerbit CV. Yasaguna.

Vergara, B.S. 1985. Komponen Hasil Unsur-unsur yang Mempengaruhi Hasil Padi. Penerbit Bhratara Karya Aksara. Jakarta. 
